\title{
Recovery Plan for Burrowing Owl in Alberta
}
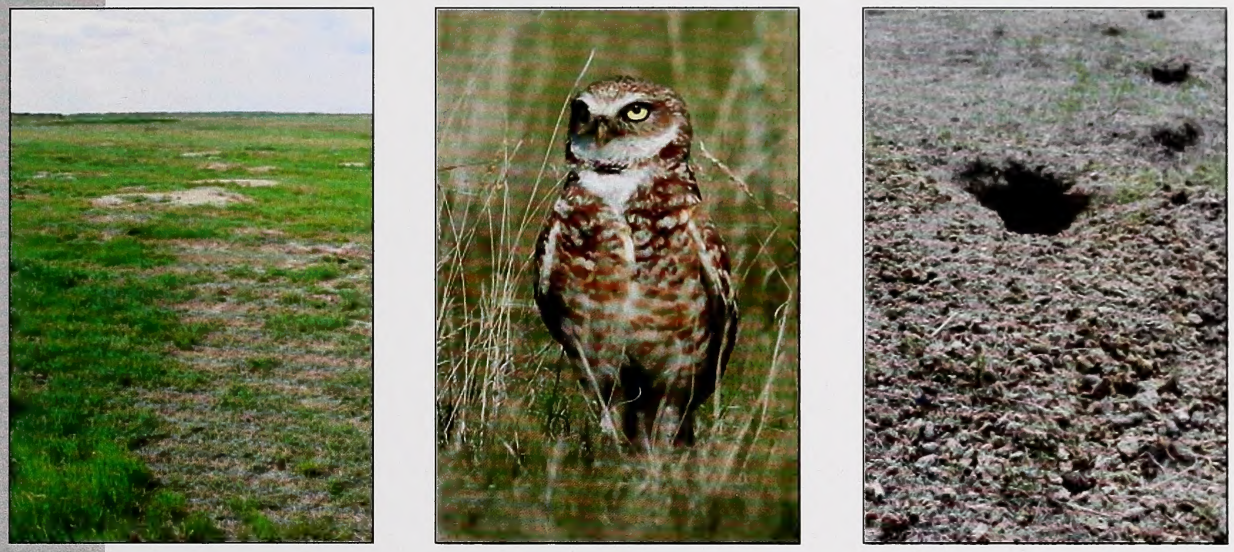

Alberta Species at Risk Recovery Plan No. 6 
Digitized by the Internet Archive in 2016 


\section{Recovery Plan for Burrowing Owl in Alberta}

Prepared by:

Alberta Burrowing Owl Recovery Team

Arlen Todd, Alberta Fish and Wildlife Division (Team Leader and Chair)

Nancy Boutilier, Alberta Public Lands James Butler, ConocoPhillips Canada Resources Corporation

Clayton Curry, Special Areas

Nic DeGama-Blanchet, Nature Conservancy of Canada

Geoffrey Holroyd, Environment Canada (ex officio)

Craig Horner, Alberta Beef Producers

Dug Major, Special Areas Board

Rick Martin, Eastern Irrigation District

Joel Nicholson, Alberta Fish and Wildlife Division

Reg Russell, Alberta Fish and Wildlife Division (Secretariat)

Dave Scobie, Member-at-large

Ivan Shukster, Grasslands Naturalists

Lindsay Tomyn, Operation Grassland Community (Alberta Fish and Game Association)

Catherine Watson, EnCana Corporation

Troy Wellicome, Environment Canada

\section{December 2005}

\section{Alberta}


Publication No. I/229 (Printed, On-line Edition)

ISBN: 0-7785-4511-3 (Printed Edition)

ISBN: 0-7785-4512-1 (On-line Edition)

ISSN: 1702-4897 (Printed Edition)

ISSN: 1702-4900 (On-line Edition)

Cover Photos: R. Poulin (left, right), G. Court (centre)

For copies of this report, contact:

Information Centre - Publications

Alberta Sustainable Resource Development

Main Floor, Great West Life Building

9920108 Street

Edmonton, Alberta, Canada T5K 2M4

Telephone (780) 422-2079

OR

Visit the Alberta Species at Risk Program web site at:

http://www3.gov.ab.ca/srd/fw/speciesatrisk/

This publication may be cited as:

Alberta Burrowing Owl Recovery Team. 2005. Recovery plan for burrowing owl in Alberta. Alberta Sustainable Resource Development, Fish and Wildlife Division, Alberta Recovery Plan No. 6, Edmonton, AB. 24 pp. 


\section{PREFACE}

Albertans are fortunate to share their province with a diverse variety of wild species. Populations of most species of plants and animals are healthy and secure. However, a small number of species are either naturally rare or are now imperilled because of human activities. Recovery plans establish a basis for cooperation among government and stakeholders to ensure these species and populations are restored or maintained for future generations.

Alberta's commitment to the Accord for the Protection of Species at Risk and to the National Framework for the Conservation of Species at Risk, combined with requirements established under Alberta's Wildlife Act and the federal Species at Risk Act, has resulted in the development of a provincial recovery program. The overall goal of the recovery program is to restore species identified as Threatened or Endangered to viable, naturally self-sustaining populations within Alberta.

Alberta species at risk recovery plans are prepared under the supervision of the Fish and Wildlife Division, Alberta Sustainable Resource Development. These recovery plans are prepared by recovery teams composed of a variety of stakeholders including conservation organizations, industry, landowners, resource users, universities, government agencies and others. Membership is by invitation from the Director of Wildlife Management, and includes representation from the diversity of interests unique to each species and circumstance. Conservation and management of these species continues during preparation of the recovery plan.

Recovery plans include three main sections: background information that highlights the species' biology, population trends and threats; a recovery section that outlines goals, objectives, and strategies to address the threats; and an action plan that profiles priority actions required to maintain or restore the Threatened or Endangered species.

These plans are provided by the recovery team as advice to the Minister of Sustainable Resource Development (the Minister; the Department) and to all Albertans. The Department, other provincial departments, as appropriate, and Alberta's Endangered Species Conservation Committee review draft recovery plans, and provide recommendations to the Minister. In addition, an opportunity for review by the public is provided.

Approved plans are a summary of the Department's commitment to work with involved stakeholders to coordinate and implement conservation actions necessary to restore or maintain these species. Recovery plans are "living" documents and are revised as conditions change or circumstances warrant. Implementation of each recovery plan is subject to the availability of resources, from within and from outside government.

The Recovery Plan for Burrowing Owl in Alberta was reviewed by the Endangered Species Conservation Committee in March 2005. The committee subsequently recommended to the Minister that the plan be approved with minor revisions, and implemented. On December 16, 2005, the Minister approved the recovery plan and directed the Department to implement the plan to guide the recovery program for burrowing owl in Alberta. 


\section{TABLE OF CONTENTS}

PREFACE iii

ACKNOWLEDGEMENTS vi

EXECUTIVE SUMMARY vii

1.0 INTRODUCTION

1.1 Ministerial Conservation Action Statement

1.2 Recovery Team 1

1.3 Guiding Principles

2.0 BURROWING OWL BIOLOGY 2

2.1 Range, Distribution, and Population Trends of the Burrowing Owl __ 2

2.2 Natural History Characteristics and Habitat Requirements ___ 4

2.2.1 Nesting and Roosting Habitat

2.2.2 Foraging Habitat

2.2.3 Essential Habitat 1

3.0 POPULATION THREATS AND LIMITING FACTORS

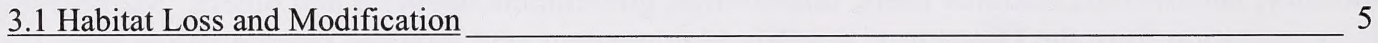

3.2 Mortality of Mature Birds on Breeding Grounds ___ 6

3.3 Low Productivity __ 6

3.4 Human Disturbance, Industrial Development __

4.0 KNOWLEDGE GAPS ____ _

5.0 RECOVERY

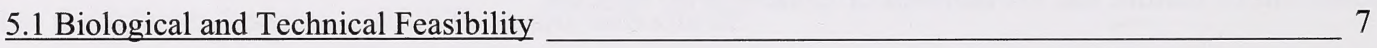

5.2 Recovery Goal __ 7

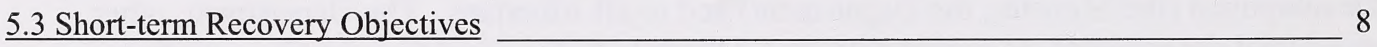

5.4 Recovery Strategies ___ 8

6.0 APPROACHES TO ACHIEVE RECOVERY STRATEGIES ___ 8

6.1 Rangeland Management and Stewardship ___ 8

6.2 Retaining or Increasing Habitat

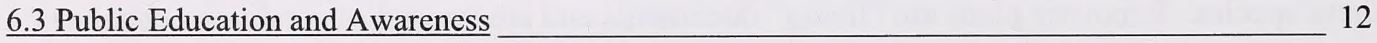

6.4 Optimizing Survival _ 13

6.5 Causes of Decline _ 15

6.6 Productivity _ 15

6.7 Population Monitoring _ـ 16

$\begin{array}{ll}7.0 \text { ACTION PLAN __ } & 16\end{array}$

$\begin{array}{ll}7.1 \text { Maintenance } & 16\end{array}$ 
$\underline{\text { 8.0 TIMETABLE FOR IMPLEMENTATION AND SCHEDULE OF COSTS }}$ 19

9.0 PLAN REVIEW, AMENDMENT, AND IMPLEMENTATION 19

\begin{tabular}{ll}
10.0 SOCIO-ECONOMIC CONSIDERATIONS & 20 \\
\hline
\end{tabular}

Agriculture 20

Other Industry

Recreation

Natural Capital 21

11.0 LITERATURE CITED 22

\section{LIST OF FIGURES}

Figure 1. Distribution of the burrowing owl in Canada in the 1970s, 1993, and 2004 3 


\section{ACKNOWLEDGEMENTS}

Members of the Alberta Burrowing Owl Recovery Team thank their respective organizations for providing in-kind support for the preparation of this plan. We also thank Dave Stepnisky for a large contribution of compiled information, and Michelle MacLean, Kelley Kissner, and Anne Forshner for assistance with revisions. Danielle Todd provided the distribution map. Steve Brechtel, Sue Cotterill, Gord Court, and Dave Prescott provided reviews. We acknowledge former team members (and their employers), as follows: Allan Goodfellow (EnCana Corporation); Margaret Green (Nature Conservancy of Canada); Kerry Grisley (Operation Grassland Community, Alberta Fish and Game Association); Stuart Lunn (PanCanadian Energy Corporation); Maria Big Snake and Cedric Solway (Siksika Nation).

The Species at Risk Program of Alberta Sustainable Resource Development funded the preparation of the recovery plan. 


\section{EXECUTIVE SUMMARY}

The burrowing owl (Athene cunicularia hypugaea) is a small owl (20 cm long) that breeds, in Canada, in the open prairies of Alberta and Saskatchewan, and winters in the southern U.S. and Mexico. Burrowing owls are most commonly found on the ground since they nest in abandoned ground squirrel (Spermophilis sp.) and badger (Taxidea taxus) burrows in native prairie. During the day, the owls forage close to their burrows (mostly for insects); at night, they venture slightly further to find small mammals.

The geographic range of the burrowing owl is shrinking; it has been extirpated from British Columbia, Manitoba, Iowa and Minnesota. Listed as an Endangered species in Canada, the burrowing owl is Threatened in Alberta. In Alberta, burrowing owl populations have shown a steep and continuing decline, then remained low. A number of factors may have contributed to the burrowing owl's decline: habitat loss and modification; low productivity; mortality on the breeding, migration, or wintering grounds; and human and industrial disturbance. Habitat is reduced through the conversion of native prairie and grazing land to cultivation, which also causes fragmentation of the grasslands. The loss of grassland habitat also reduces suitable habitat for some of the owl's prey species and for the burrowing animals on which the owls depend for nesting sites. Mortality on the breeding range can be affected by an increase in predators, starvation, disease, and collisions with vehicles. These factors, as well as the use of pesticides and other toxic chemicals, contribute to low productivity. Human disturbance may result in loss or degradation of habitat, altering prey and predator populations, and may also cause nest abandonment.

The recovery goal is to increase the population of the burrowing owl in Alberta to viable, naturally self-sustaining levels, with the species well distributed throughout its range. To accomplish this goal, three short-term objectives have been identified: 1) To stop the decline of the burrowing owl population in Alberta by 2009; 2) To reverse the documented shrinkage of burrowing owl range in Alberta, restoring distribution to earlier (1993) levels; 3) To maintain, increase, and enhance habitat for burrowing owls in Alberta.

Strategies for the recovery of burrowing owl populations in Alberta must focus on the identified threats to the species, its prey, and habitats. Therefore, the recovery strategies for the burrowing owl are: 1) Determine beneficial management practices and encourage stewardship, using the best available knowledge, to enhance the quality of burrowing owl habitat and increase burrowing owl densities; 2) Develop and encourage the implementation of policies and programs that retain or increase the amount of burrowing owl habitat; 3 ) Increase support for burrowing owl and prairie conservation through public education and awareness programs; 4) Optimize survival of burrowing owls; 5) Determine the causes of declines of burrowing owls; 6) Optimize productivity of burrowing owls; 7) Monitor populations of burrowing owls.

Alberta populations of burrowing owls are impacted by mortality factors and habitat influences on migration and wintering areas outside of Alberta. Approaches to deal with these broaderlevel concerns and influences are covered in the National Recovery Strategy (in preparation). 


\subsection{INTRODUCTION}

\subsection{Ministerial Conservation Action Statement}

In February 2000, the Minister of Environment (now Sustainable Resource Development) affirmed the status listing of the burrowing owl as Threatened under Alberta's Wildlife Act, following a review of the species' status and a recommendation by the Alberta Endangered Species Conservation Committee. The designation of Threatened was based on a population reduction of at least $30 \%$ in the preceding 10 years, long-term reduction in provincial distribution, small population size (less than 1000 pairs), and the consideration that some Alberta populations appeared stable (therefore, the Endangered status category was inappropriate). The action statement, approved by the Minister, directed that a provincial recovery plan should be prepared within the next 24 months, that all those with a stake in burrowing owl issues should be invited to participate in recovery planning, and that additional resources should be secured to support essential conservation actions. Furthermore, the action statement urged that government land use management systems should be strengthened to ensure no net loss of nests as a result of managed activities (industrial, agricultural, or recreational).

\subsection{Recovery Team}

At the direction of the Minister of Sustainable Resource Development, The Alberta Burrowing Owl Recovery Team was initiated in 2001 by the Director of Wildlife Management. The Team presently includes a member-at-large, and representatives from Alberta Beef Producers, Alberta Fish and Game Association, Alberta Sustainable Resource Development, Environment Canada, ConocoPhillips Canada Resources Corporation, Eastern Irrigation District, EnCana Corporation, Grasslands Naturalists, Nature Conservancy of Canada, and Special Areas Board. The primary responsibility of the Team is to guide recovery efforts in Alberta through development and implementation of a plan that outlines recovery strategies and actions necessary to recover burrowing owl populations in the province.

\subsection{Guiding Principles}

The Alberta Burrowing Owl Team has operated from a core set of principles that include the following:

- The effective involvement of all concerned Albertans may be essential to ensure that the burrowing owls is not extirpated as a result of human activities. It may take a very large, collective will to determine the effects of human developments on burrowing owls, and to develop and encourage positive problem-solving strategies and approaches. Basic lifestyle choices of humans do impact species at risk, unless developmental effects are mitigated. Nonetheless, needless impacts on humans must be avoided, as well. This recovery planning process has sought to reach the appropriate balance.

- Governments have a lead role to play in facilitating the recovery of burrowing owls. However, the success of recovery efforts depends, as always, on the knowledge and commitment of organizations and individuals that own, manage, and use the land, namely landholders and resource users. 
- Conservation and recovery programs for burrowing owls will be founded on voluntary, cooperative efforts that are cost-shared on an equitable basis. Economic and social costs of recovery actions (including loss, sacrifice, efforts, and outlay of time and trouble) will be duly considered at all points in the recovery planning and implementation processes.

Nevertheless, the team encourages the elimination of any government policy disincentives to landowners to protect species at risk. Further, the team encourages and supports incentives (indirect and direct, as required) that protect species at risk.

- Lack of full scientific certainty should not be used as a reason for postponing measures or actions to achieve conservation or recovery of burrowing owl populations.

With respect to landholders and other stakeholders, the Alberta Burrowing Owl Recovery Team has been guided by the following principles:

- The historical and ongoing stewardship efforts of landholders in maintaining habitats for burrowing owls are both acknowledged and appreciated.

- There is demonstrable value in strengthening relationships between the land stewards and others who have an interest in maintaining or enhancing habitats for burrowing owls.

- Individual stakeholder groups should not be unduly impacted by costs associated with maintaining or enhancing burrowing owl habitat, or other recovery efforts.

\subsection{BURROWING OWL BIOLOGY}

\subsection{Range, Distribution, and Population Trends of the Burrowing Owl}

The burrowing owls found in Canada are the western subspecies, Athene cunicularia hypugaea. Approximately $4 \%$ of the range of the western burrowing owl is located in Canada; the majority of range occurs in the United States (Wellicome and Holroyd 2001). In Canada, the owl is currently found only in Alberta and Saskatchewan, where its breeding range has been shrinking (Figure 1). It has been extirpated from British Columbia and Manitoba (Figure 1). The burrowing owl is listed as an Endangered species, at the national (Canadian) level, as opposed to Threatened in Alberta. These status designations and trends for the owl are very likely symptoms of larger environmental problems in grassland ecosystems across the continent.

Canadian burrowing owls are migratory. While little is known about where these birds overwinter, several Canadian owls are known to have spent the winter months during 1999-2001 in southern Texas and the central regions of Mexico (G. Holroyd pers. comm.). It is recognized that Alberta populations of burrowing owls are impacted by mortality factors and habitat influences on migration and wintering areas outside of Alberta. Approaches to deal with those broader concerns and influences are covered in the National Recovery Strategy (in preparation).

In Alberta, data show steep population declines. Breeding pairs declined from 243 pairs in 1991 to 24 pairs in 2001 and 2002 (on lands held by respondents to Operation Grassland Community), and have remained low, but increased somewhat since (31 pairs in 2003, 53 pairs in 2004). Near Hanna, very steep population declines were also observed — about $90 \%$ over 6 years [1991-1997; 
from 33 down to 3 nests per $100 \mathrm{~km}^{2}$ (Shyry et al. 2001)]. Near Brooks, low-density populations were recorded (about 10-14 nests per $100 \mathrm{~km}^{2}$ ) and shown to be somewhat more stable initially, but they declined by two-thirds during 1997-2002 (Russell 2002), and remained low through 2004 (D. Shyry pers. comm).

Burrowing owls occur in native grassland portions of southeastern Alberta. The northern and western peripheries of the species' range are known to have contracted over the past 35 years. In 2004, burrowing owls can be found primarily in the area spanning north from the Montana border to the vicinities of Hanna and Youngstown, and west from the Saskatchewan border to the vicinities of Coutts, Warner, Coaldale and Drumheller (Figure 1). It is recognized that burrowing owl distribution is not continuous throughout the area just described; unoccupied areas have yet to be delineated at a finer scale.

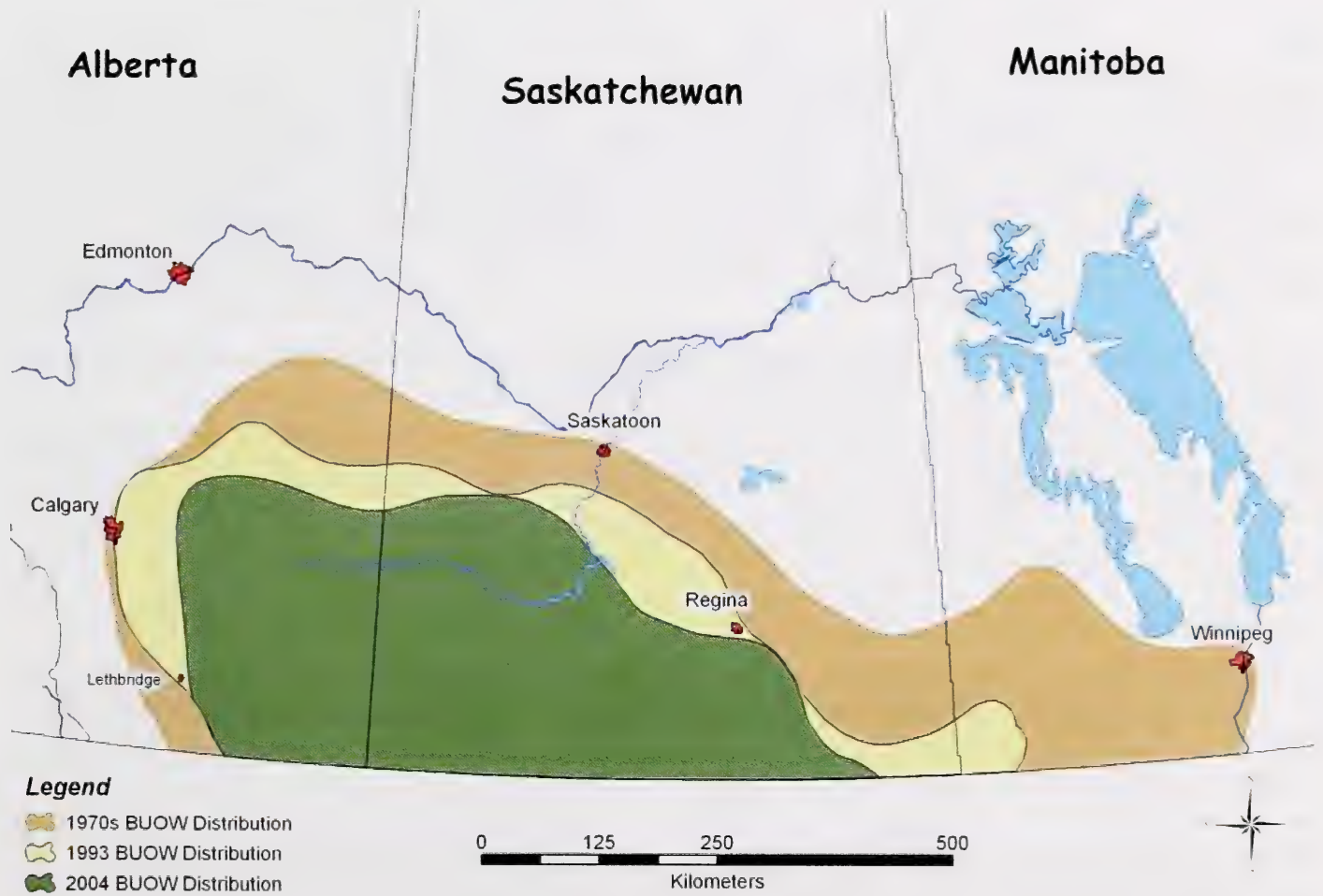

Figure 1. Distribution of the burrowing owl in Canada in the 1970s, 1993, and 2004.

Distribution is not continuous throughout the range indicated in 2004. The 1993 distribution is selected as the benchmark for range restoration. 


\subsection{Natural History Characteristics and Habitat Requirements}

Alberta's burrowing owls return from their wintering areas in April and May. Since they nest in abandoned burrows, they are highly dependent on the fossorial (digging or burrowing) mammals that create these burrows. Nest chambers and burrows are lined with dried, shredded manure, and the male provides food to the female during courtship and throughout the incubation period (Wellicome and Haug 1995).

Clutch sizes range from six to 11 eggs, averaging nine (Wellicome and Haug 1995). Young are altricial (immobile, eyes closed, dependent on parents on feeding) and will often die from starvation and cannibalism during natural food shortages. Fledglings begin using nearby (satellite) burrows at about 25 days of age and are capable of sustained flight at 50 days old. They become independent of the adults between 60 and 70 days of age (Wellicome and Haug 1995).

In southern Alberta the average home range for adult males is about $3 \mathrm{~km}^{2}$ (Sissons 2003). Within this area, burrowing owls usually have a matrix of several habitat types in order to meet their nesting and foraging requirements. They require an open area with an adequate nest burrow surrounded by short vegetation, and enough permanent cover and taller vegetation $(30-60 \mathrm{~cm})$ within their foraging home range to supply a sufficient amount of small mammals and other prey. Burrowing owls require habitats in two broad categories: nesting/roosting, and foraging.

\section{$\underline{\text { 2.2.1 Nesting and Roosting Habitat }}$}

Three basic characteristics of nesting habitat for burrowing owls are available nest burrows, short $(<10 \mathrm{~cm})$ or sparse vegetation, and open terrain (Zarn 1974). Enlarged ground squirrel (Spermophilis sp.) burrows, badger (Taxidea taxus) excavations, and occasionally abandoned fox (Vulpes sp.) and coyote (Canis latrans) dens are used for nesting (as well as for roosting and caching food). In Alberta (as elsewhere), burrowing owls nest primarily in native prairie (Clayton and Schmutz 1999). Studies in other locations have begun to elucidate the characteristics of successful nesting habitats. James et al. (1991) found burrowing owls preferred pastures that were grazed and with higher burrow availability. Warnock and Skeel (2001) observed successful nests to have more clusters of ground squirrel and badger holes nearby, as well as more riparian habitat within $2 \mathrm{~km}$, more grassland habitat within $2 \mathrm{~km}$, fewer single trees nearby, lesser lengths of visible fences, fewer perches for larger owls (i.e., potential predators), and greater distances to farmyards.

Burrowing owls use burrows for roosting, in addition to nesting. Adult and juvenile owls use non-nesting (satellite) burrows, which likely optimizes survival.

\subsubsection{Foraging Habitat}

During the day, foraging is confined to the vicinity of the nest burrow (Gleason 1978, Haug and Oliphant 1990) and thus is usually in pastureland. Burrowing owls hunt almost exclusively for insects during the day, while small mammals (which comprise the majority of the biomass intake) are primarily captured at night, further from the nest (Haug and Oliphant 1990, Plumpton 
1992). Foraging over uncultivated areas and roadside habitats has been recorded (Haug and Oliphant 1990); those habitats had dense, permanent vegetation, greater than $30 \mathrm{~cm}$ in height. Because small mammals prefer such areas, it is likely that the owls are foraging in areas with higher abundance of microtine (small mammal) prey. Haug and Oliphant (1990) found adult burrowing owls avoided cropland and heavily grazed pastures for foraging.

\subsubsection{Essential Habitat}

Although basic characteristics of nesting and foraging habitats are known, the specific habitat requirements of the species are not. Nesting and foraging habitats are likely key components of essential habitat, however, further research is required to identify essential habitat and its key attributes for burrowing owls. Once essential habitat is identified, the activities that could lead to its destruction, and the measures already in place or required to protect it can be determined.

\subsection{POPULATION THREATS AND LIMITING FACTORS}

A number of factors probably combine to explain the downward trend in burrowing owl populations in Alberta. Threats and limiting factors that affect the owls are categorized as habitat loss and modification, mortality of mature birds on the breeding grounds, low productivity, mortality on migration or wintering grounds, as well as human disturbance and industrial development. Mortality on migration and wintering grounds is not covered in this document, but indications are that such losses may be substantial [refer to the National Recovery Strategy (in preparation)].

\section{$\underline{3.1 \text { Habitat Loss and Modification }}$}

Over the past century, the cumulative effects of intensive agriculture, urban sprawl, petroleum and natural gas developments, road building, irrigation, and other human land uses have contributed to the loss, fragmentation and degradation of half or more of the native prairie in Alberta. Pasture lands decreased by 8\% in Alberta's burrowing owl range during 1966-1991 (Wellicome and Haug 1995); decrease has continued since then, but has not been quantified.

There is clearly a positive relationship between burrowing owls and ranching; both are largely reliant on native grasslands in the Dry-Mixedgrass prairie. Moreover, the burrowing owl requires short grass as a component of its nesting area, so it frequently resides in grazed grassland (Wedgwood 1976, Hjertaas et al. 1995, Clayton 1997). Therefore, the conversion of pastureland to cultivation negatively impacts populations of burrowing owls. In addition, fragmentation of grassland habitat may cause the communities or populations of predators to change, and numbers of key prey species to decrease. The loss of grassland habitat also reduces suitable habitat for fossorial mammals, which the burrowing owls depend on to create burrows for nesting.

The suitability of grasslands for burrowing owls is affected by climate, weather, and grazing intensity. Drought and grazing intensity may have acted in concert to reduce suitability of some foraging habitats for burrowing owls in Alberta (see also Hull et al. 2004). 


\section{$\underline{3.2 \text { Mortality of Mature Birds on Breeding Grounds }}$}

Predation has been shown to be the major cause of adult mortality (largely by avian predators, and by badgers on females), followed by starvation/disease, and vehicular collisions (T. Wellicome and R. Sissons pers. comm.).

Because burrowing owls nest below ground, they are vulnerable to both avian and ground predators. Ground predators that enter nest burrows (and prey on adult females, as well as eggs and nestlings) include badgers, foxes, striped skunks, weasels, raccoons, snakes, and domestic cats (Sleno 2000). Predators above the ground include coyotes, domestic dogs and cats, Swainson's hawks, great horned owls, ferruginous hawks, northern harriers, short-eared owls and prairie falcons (Wellicome and Haug 1995). Additions to the prairie landscape within the last century, such as fences, utility poles, hedgerows, trees, and artificial nests for hawks have enhanced habitat quality for large raptors (Schmutz et al. 1984), but may contribute to increased predation on burrowing owls.

Collisions with vehicles and fences have been identified as causes of mortality (Wellicome 1997a, Todd 2001a). The increase in road networks across burrowing owl nesting, migration and wintering ranges, combined with the owls' use of roadside ditches as alternative foraging habitat, represent significant changes in the landscape that may be contributing to increased mortality due to collisions with vehicles (K. DeSmet pers. comm.).

\section{$\underline{3.3 \text { Low Productivity }}$}

Low productivity could be caused by low breeding rates (proportion of pairs breeding), high rates of nest failure (i.e., nesting attempted but no young produced, due to nest desertion or flooding, predation of eggs, or inviable embryos), or high mortality of young following hatching. Other contributing factors include habitat degradation, pesticides, declines in prey populations, disturbance, predation, cannibalism, accidents, shooting, weather, parasites, and diseases.

Predators are the primary cause of post-fledging mortality (Shyry and Todd 2000, Todd 2001a). Collisions with vehicles and fences are the second greatest cause of juvenile mortality (Shyry and Todd 2000).

Insecticides and rodenticides are used in the province to control insects and burrowing mammal populations. Although the use of these chemicals is not intended to impact the burrowing owl, indirect effects through ingesting poisoned rodents and insects can be serious. For example, James et al. (1990) observed that owls in pastures treated with strychnine-coated grain weighed less than owls in control pastures. The insecticide Carbofuran, which currently has restrictions on its use (and an Alberta advisory in place), is known to have detrimental effects on burrowing owls through increased adult mortality and lower reproductive performance (James and Fox 1987).

Prey populations may have been variously affected (both positively and negatively) over past decades by programs to control rodent and insect populations, by cattle grazing, and through cultivation of grasslands. Healthy prey populations are critical for the reproductive success of 
burrowing owl, as evidenced by Wellicome (1997b), who found that artificially increasing food levels for nestlings increased the number of young fledged.

\section{$\underline{\text { 3.4 Human Disturbance, Industrial Development }}$}

Disturbance may cause failure of burrowing owl nests, through desertion (D. Scobie pers. comm.) The effects of disturbance are known, in general, to vary with the timing, nature, regularity, intensity and duration of disturbance, as well as factors such as individual differences among animals and habituation to the disturbance.

\subsection{KNOWLEDGE GAPS}

Further understanding of the factors responsible for burrowing owl declines is sorely needed. Another important knowledge gap is what happens to the very large proportions of Alberta birds (juveniles, adults) that do not return. Further knowledge gaps are identified in the following sections of this recovery plan, and in the National Recovery Strategy [e.g., identification of essential habitat, development of beneficial management practices (including resource selection analyses), research on the cumulative effects of habitat changes, and identification of thresholds for development].

\subsection{RECOVERY}

\subsection{Biological and Technical Feasibility}

There is potential for the recovery of the Alberta population of burrowing owls. While proximate and ultimate causes of burrowing owl declines are not conclusively known, the declines are probably caused by a number of contributing factors. That uncertainty may hamper the achievement of recovery goals in the near-term. Moreover, breeding populations are not well documented. Nevertheless, this recovery plan does identify some near-term priorities and actions that may help reverse trends over the longer term.

Maintaining and restoring habitat effectiveness will be a key to achieving recovery.

Development and effective implementation of beneficial management practices and land use guidelines (considering cumulative effects) and habitat restoration are integral actions. Other productive approaches will include: furthering understanding of habitat requirements and risks to habitats, and mitigating those risks; stewardship programs; and measures to improve survival and productivity of burrowing owls.

\section{$\underline{5.2 \text { Recovery Goal }}$}

Increase the population of the burrowing owl in Alberta to viable, naturally self-sustaining levels, with the species well-distributed throughout its recent (e.g., 1993 - see Figure 1) range. 


\subsection{Short-term Recovery Objectives}

- Stop the decline of the burrowing owl population in Alberta by 2009 .

- Reverse the documented shrinkage of burrowing owl range in Alberta and restore distribution to earlier (1993) levels.

- Maintain, increase, and enhance habitat for burrowing owls in Alberta.

\subsection{Recovery Strategies}

Strategies for recovery of burrowing owl populations in Alberta must focus on the identified threats to the species, its prey, and habitats (see Section 3.0, Population Threats and Limiting Factors). Therefore, the recovery strategies for the burrowing owl are:

1. Determine beneficial management practices and encourage stewardship, using the best available knowledge, to enhance the quality of burrowing owl habitat and increase burrowing owl densities;

2. Develop and encourage the implementation of policies and programs that retain or increase the amount of burrowing owl habitat;

3. Increase support for burrowing owl and prairie conservation through public education and awareness programs;

4. Optimize survival of burrowing owls;

5. Determine the causes of declines of burrowing owls;

6. Optimize productivity of burrowing owls;

7. Monitor populations of burrowing owls.

\subsection{APPROACHES TO ACHIEVE RECOVERY STRATEGIES}

The Recovery Strategies provide a framework for achieving the long-term maintenance and recovery of the burrowing owl in Alberta. The following approaches and actions, which support the Recovery Strategies, can be pursued opportunistically by recovery team member organizations and all Albertans.

\subsection{Rangeland Management and Stewardship}

Determine beneficial management practices and encourage stewardship, using the best available knowledge, to enhance the quality of burrowing owl habitat and increase burrowing owl densities

1. Continue to promote public reporting systems to identify occupied sites.

[e.g.,: Operation Grassland Community (OGC) and Biodiversity Species Observation Database (BSOD); Siksika and Blood Nations, naturalists (Atlasing, Breeding Bird Survey), industry consultants] 
- Manage public access to the BSOD database about burrowing owls, which will protect confidentiality of nest sites, and alleviate landholder concerns.

- Encourage Alberta Natural Heritage Information Centre observations on burrowing owls to cross-reference to BSOD.

2. Promote habitat conservation programs in support of private landholders.

- Encourage OGC membership.

- Advise landholders of programs such as those offered by the Nature Conservancy of Canada, and others who can hold easements [Ducks Unlimited (Canada), Alberta Sustainable Resource Development, Alberta Conservation Association, Operation Grassland Community, Southern Alberta Land Trust Society].

- Provide input and support to Alberta Environmental On-farm Planning to ensure burrowing owl habitat needs are incorporated.

3. Work with landholders (public and private) and stakeholders to develop and implement BMPs for the burrowing owl.

- Undertake research to determine BMPs.

- Determine the impact of these practices on other species and on landholders.

- Support range health assessment projects and protocols, to provide assessments related to burrowing owl habitat.

- Implement habitat stewardship programs (e.g., Special Areas HSP for Species at Risk).

- Maintain native rangelands for multi-use needs.

- Ensure consideration of burrowing owls in integrated land management decisions.

- Encourge the continued use of construction/development practices that minimize impacts on the native prairie.

4. Ensure adequate numbers and distribution of nest burrows (badgers, ground squirrels).

4.1 Encourage land managers to maintain populations of fossorial mammals that provide burrows for burrowing owls.

- Influence through education.

- Determine what level of acceptance landowners have for fossorial mammals.

4.2 Use policies and existing regulations, and extension and education programs, to ensure that trapping, poisoning, and hunting do not eradicate local populations of fossorial mammals.

5. Ensure adequate habitat to support prey populations.

- Implement range management practices that ensure taller grass cover in foraging areas.

- Deliver an education program that encourages a mosaic of habitat types on native prairie.

5.1 Inform land managers of the burrowing owl's preference for a mosaic of range regimes. Consider incentives for land managers (and others) that maintain burrowing owl habitat.

- Deliver through education (i.e., OGC fact sheet). 
- As land stewards, landholders should be informed of how to encourage successful nesting of burrowing owls on their land. Structural heterogeneity is important across the prairie landscape. Examples of possible management suggestions include: 1) maintain grazing at and very near owl nest sites; 2) maintain riparian areas and expand, where possible, taller, dense grass cover areas near owl sites to provide foraging habitat; 3 ) reduce heavy livestock use at immediate nest sites during nesting and brood rearing to lessen trampling risks; 4) vary stocking rates in accordance with precipitation; 5) promote heterogeneous habitat conditions by patch grazing to effect patches of differing use and grass height, and varying residual vegetation and litter cover; 6 ) avoid intensive, high stocking rate grazing systems across large areas (see also Hull et al. 2004).

6. Conserve and manage habitat for a diversity of species including the burrowing owl.

- Communicate with other recovery teams and initiatives to identify and resolve conflicts.

\subsection{Retaining or Increasing Habitat}

\section{Develop and encourage the implementation of policies and programs that retain or increase the amount of burrowing owl habitat}

1. Develop and encourage incentives for landholders and others to conserve burrowing owls.

- Implement habitat stewardship programs in priority areas, as identified by the Alberta Burrowing Owl Recovery Team.

- Develop other incentives, as feasible.

1.1 Identify and recommend land use policies and practices that encourage enhancement of burrowing owl habitat or minimize impacts of industrial development (e.g., placing industrial easements on cultivated sites, rather than on native prairie, to maximize prairie conservation).

1.2 Examine agricultural support programs to ensure that they conserve burrowing owls, other prairie wildlife and their natural habitats, as well as modify programs to encourage maintenance of native prairie, and the restoration of marginal cropland to pasture. Balance the needs of burrowing owls with sound range management and the needs of landowners and other wildlife.

1.3 Encourage the use of guidelines and other provisions to buffer owl nests from activities of industry to reduce the loss of owl habitat and to limit disturbance to nesting owls.

- Use of existing guidelines, which recommend buffer zones and times for oil and gas activity near burrowing owl sites (Scobie and Faminow 2000, web http://www3.gov.ab.ca/srd/fw/landuse/index.html), should be encouraged. Research should be conducted to refine the guidelines, expand them to other industrial activities, including measurements of ambient sound, and assess their effectiveness.

- Encourage the development and use of BMPs and codes of practice (develop in cooperation with industries, organizations that represent industries, landowners, and government regulators, such as the Energy and Utilities Board).

- Inform landowners and landholders of the BMPs and codes of practice, and encourage their use; potential benefits are multiple, and include burrowing owl conservation. 
1.4 Determine the rate of loss of suitable nesting and foraging habitat, and determine the causes of habitat loss.

- Information exists on present and historic footprints on the landscape. The information on habitat loss presented in Wellicome and Haug (1995) should be updated and used to identify landscape changes in the breeding range of burrowing owls. Such a study should incorporate losses to other species' habitat where appropriate.

1.5 Investigate the cumulative impacts of human activity on the burrowing owl.

- With the increasing human footprint on the prairie landscape, the cumulative impact of all activities on prairie wildlife should be determined on a landscape scale. Prairiespecific models have been developed to investigate cumulative impacts, and burrowing owls should be incorporated into these models to gain an understanding of long-term trends and their impact on burrowing owls. Climate change should also be incorporated into this landscape model.

1.6 Continue to develop policy and conservation solutions to reduce conflicts that develop when burrowing owls nest near airports, on construction sites, or in other developed areas to ensure the protection of owls.

- Identify locations and activities of concern (e.g., cities of Calgary, Medicine Hat).

- Guidelines and/or regulations to minimize disturbance of nesting areas (including auditory disturbance) to avoid nest site abandonment, vandalism, or nest failure should be tested and implemented to guide wildlife agency personnel in resolving human/owl conflicts.

- Nest sites that are located in areas of high traffic should be closely monitored and given special protection, if required.

- Consider further mitigative measures, as required.

1.7 Encourage environmental screening for land use changes and urban/industrial development on grassland habitats (Scobie and Faminow 2000).

- Through communication of owl nest site locations and habitat requirements of owls to developers, measures to protect burrowing owl nest and roost sites can be incorporated into new projects.

2. Ensure integrated land management planning processes include burrowing owl conservation issues.

- Provide input to developments.

3. Develop programs to manage burrowing owl habitat on land controlled by all levels of government.

- Work with public land management agencies to ensure maintenance of prime burrowing owl habitat through a variety of arrangements, including conservation and protective notations, timing constraints, and other mitigative measures.

4. Identify essential habitats that must be managed to achieve population goals (both maintenance and recovery habitats).

4.1 Document characteristics of occupied and unoccupied nest sites. 
- Through many years of investigation, land managers, biologists and others have a good concept of what nesting habitat burrowing owls are using; however, this knowledge has never been compiled in a central document. A workshop to synthesize existing knowledge and identify any knowledge gaps should be held as soon as possible (Environment Canada host).

4.2 Document characteristics of foraging sites used by burrowing owls.

- Similar to the preceding item, biologists and land managers should compile current knowledge of burrowing owl foraging areas and determine what else needs to be learned about this aspect of burrowing owl biology (Environment Canada host).

4.3 Identify and map suitable and potentially suitable burrowing owl habitats.

- Assess the utility of BSOD observations of burrowing owls for determining habitat suitability (C. Gates pers. comm.).

- There is a need to identify the habitats that are important to the maintenance of burrowing owls, as well as those that will allow for population recovery and expansion. Both currently used sites (essential to maintain current owl numbers) as well as potential future habitat (needed to recover owl numbers to former levels) should be delineated to the fullest extent possible. Caution should be used when mapping areas, as the prairie landscape is dynamic and thus suitability of habitats may change on the landscape over time. The characteristics of occupied habitat identified in 4.1 and 4.2 should be interpreted using remote sensing technology to identify the geographic distribution of suitable habitat for nesting and foraging owls.

5. Increase the area and enhance the quality of burrowing owl habitat through increasing grassland patch sizes and reducing grassland fragmentation.

- Ensure reclamation is done with native seeds, and natural recovery.

- Consider consolidating lands through land exchanges, where appropriate, for multiple benefits, including burrowing owls.

- Reduce the effects of habitat fragmentation on burrowing owls and other prairie species through habitat enhancement programs. Burrowing owl habitat can be increased and enhanced (fragmentation reduced) by seeding cultivated areas that are adjacent to pastures that either have supported or presently support nesting burrowing owls.

- Encourage the continued use of construction practices that minimize disturbance to native prairie, such as minimizing surface access, conserving top soil, and others.

\section{$\underline{6.3 \text { Public Education and Awareness }}$}

\section{Increase support for burrowing owl and prairie conservation through public education and awareness programs}

1. Increase general public awareness of native rangelands, the burrowing owl, and related prairie conservation issues, through existing programs.

- Utilize and develop literature and other media material to target landowners, industry and other audiences. 
- Involve provincial-level and local natural history groups in coordinated education programs for burrowing owls (e.g., Federation of Alberta Naturalists and constituent members, such as Grasslands Naturalists, Operation Grassland Community).

- Encourage the Bird of Prey Center (Coaldale, Alberta) and other facilities, such as the Calgary Zoo, to promote burrowing owl conservation.

2. Use information and extension to encourage habitat conservation and develop a public awareness of factors affecting burrowing owl habitat.

2.1 Make direct contact with landholders and their families to explain the status of burrowing owls and potential mitigation measures (including pest control alternatives).

2.2 Present and discuss habitat issues with land use policy makers.

2.3 Develop a wildlife education activity manual that looks at agricultural practices and their effects on endangered wildlife.

- Encourage conservation of native rangeland.

3. Inform landholders that incentive programs and conservation partnerships are available.

4. Inform land management, wildlife, and enforcement personnel about the burrowing owl, its status, the recovery plan, and necessary procedures to conserve the owl and its habitat.

- Educate other land managers.

- It is essential that enforcement officers (provincial and federal) are fully knowledgeable about the species, while practicing due diligence, of course.

\subsection{Optimizing Survival}

\section{Optimize survival of burrowing owls}

1. Reduce mortality arising from predation.

- Research has indicated that a great many burrowing owls, particularly juveniles, are killed on the breeding grounds (refer to Section 3.0, Population Threats and Limiting Factors). Reducing mortality will assist population recovery.

- Encouraging populations of prey species (i.e., ground squirrels, microtines, beetles, and grasshoppers) will provide an alternative prey source for potential owl predators (Todd 2001b).

1.1 Reduce mortality arising from avian predation.

- Discourage the planting of trees on native grassland.

- Resolve conflicts with installed nesting platforms at specific sites within the owl's range.

- Investigate the extent of mortality from local nesting raptors.

- Investigate and encourage perch proofing of power lines, as appropriate.

- Investigate and encourage the use of underground power lines, as appropriate. 
- Minimize the use of cross fencing, where possible, to reduce predator perch sites near suitable burrowing owl habitat.

- Experiment with the design of fence post caps to reduce their suitability as raptor perches.

1.2 Reduce mortality arising from mammal predators.

- Fragmentation may result in an increased number of ground predators and their improved hunting efficiency, which warrants further study.

2. Reduce mortality arising from collisions with vehicles and human structures.

- When owl nests are located near roads, mortality from vehicles is a major concern, as owls often cross the roads to access foraging areas. Juvenile burrowing owls have been observed actively foraging on roads at night, which increases the likelihood of collisions with vehicles (D. Shyry pers. comm.).

- Encourage motorists to slow down between dusk and dawn.

- Encourage traffic control measures (speed, volume, timing) in association with development activities.

- Consider other mitigative measures, as required.

2.1 Use signs adjacent to selected nesting and foraging areas, seasonally, to warn motorists.

- Erect signs at known locations adjacent to burrowing owl nesting and foraging sites (in selected urban and intensively used areas, such as parks), encouraging motorists to slow down at dusk.

2.2 Investigate the use of new techniques to increase motorist awareness of burrowing owl presence.

- Mass media awareness of fledging season (e.g. local radio, television and newspaper programming).

2.3 Investigate techniques to reduce burrowing owl mortality from fences, pipeline trenches and other human structures.

3. Develop and implement programs to eliminate negative effects of pesticides on burrowing owls.

- Educate and promote awareness on the effects of pesticides, including a fact sheet to go with strychnine (used for ground squirrel control), which warns about the dangers to burrowing owls and other sensitive wildlife.

- Investigate methods of controlling weeds without cutting and spraying.

- Provide information to landholders and managers to encourage pest control that is not detrimental to burrowing owls. 


\section{$\underline{6.5 \text { Causes of Decline }}$}

\section{Determine the causes of declines of burrowing owls}

1. Encourage and conduct research on different management techniques to improve habitat for burrowing owls and their prey, and to increase owl densities (see also Hull et al. 2004).

- Although both grazing and burning are recognized as important ecological processes on the prairies, very little is known about how these two factors affect habitat for burrowing owls. Research on grazing systems, wild fires, and prescribed burns on the grasslands, and how burrowing owls respond, would be highly instructive.

2. Support climate change studies.

- Climate change in Alberta may affect burrowing owl habitat and must be investigated. There could be local applications to mitigate effects.

3. Encourage study of the relationships between burrowing owls and fossorial mammals.

4. Assess and continue to determine causes of mortality.

4.1 Conduct local investigations to monitor causes and changes in mortality rates on the breeding grounds.

- Although extensive work has been recently completed on mortality in juvenile burrowing owls, knowledge of adult mortality is still incomplete. Further research on adults is required on the breeding grounds.

4.2 Determine which characteristics of habitats surrounding nest sites correlate with breeding success/failure (nest longevity and monitoring, production, defining nest).

- While a handful of studies have looked at nesting site characteristics, further investigation would refine knowledge. Measures of ambient noise should be included.

5. Further study on demographic features of burrowing owl populations is required.

5.1 Investigate recruitment (productivity and sources of mortality).

5.2 Investigate dispersal.

- Recent analyses of band recoveries show that $40 \%$ of banded adults, but only $6 \%$ of banded juveniles, are known to return to breed. It is not known whether the remaining owls died or dispersed (i.e., are breeding elsewhere). Increased searches may disclose banded owls elsewhere.

\section{$\underline{6.6 \text { Productivity }}$}

\section{Optimize productivity of burrowing owls}

1. Continue to record productivity in specific nesting areas.

- Continue to monitor productivity, and develop a consistent method to do so, to ensure results are comparable between years and between study areas. 
2. Manage prey populations to increase owl productivity.

2.1 Determine habitat management techniques that would increase food supply and have a positive effect on productivity and survival.

- Increased food supply after hatching can increase productivity in burrowing owls; however, little information exists on how to increase prey populations through land practices, and thus increase food supply.

2.2 Study prey populations to determine how they change over space and time.

2.3 Manage habitat to maximize prey densities near burrowing owl nests.

\subsection{Population Monitoring}

\section{Monitor populations of burrowing owl}

1. Develop and maintain a database of annual population reports from burrowing owl nest sites to monitor annual population and distribution changes.

- Although annual reports from selected sites may overlook local population movements, they still provide useful long-term data. At present, this is the best database available from most of the prairies. Annual population reports should be obtained from landholders known to have nesting burrowing owls. Through programs like that of Operation Grassland Community, population information can be obtained at low cost.

2. Monitor long-term trend blocks in the Brooks (Kininvie) area annually. Revisit the trend blocks in the Hanna area, where burrowing owls are nearly extirpated, once every five years. Consider additional monitoring areas over the longer term.

\subsection{ACTION PLAN}

This section presents a list of measurable, high-priority actions to be undertaken during the life of this recovery plan; many key actions will occur during the first two years, while others will occur later. Actions are organized into 'Maintenance' and 'Recovery' categories. Maintenance actions are those that are required to maintain the burrowing owl population and distribution at existing (2004) levels. Recovery actions are those that are required (within the limits of existing knowledge) to ensure self-sustaining viability of the species.

\subsection{Maintenance}

1. Identify where nesting burrowing owls currently are, and where they have been for the past two years (chosen because burrows have never been known to be reoccupied once vacant for more than one year). These sites, and the home ranges which average about a 1-kilometre radius around the burrows, contribute essential habitat.

- Conduct direct inventories (field surveys, targeted surveys) and assimilate relevant information from other sources (e.g., OGC, public lands, pre-development surveys, collect further data on longevity of burrows). 
- Develop and utilize Habitat Suitability Index/Indices as an indirect means of determining where burrowing owls should be, and might be.

- Encourage data sharing, including pre-development survey information from industry (may require policy clarification on access to species at risk data).

2. Maintain the ability of nesting areas to produce burrowing owls (i.e., maintain the quality and quantity of current, essential habitats).

- Identify key attributes of essential habitat (badgers, ground squirrels, holes, food sources) and identify habitat requirements.

- Identify risks to habitat, including ambient sound from industrial disturbance.

- Implement protection measures to mitigate risks [e.g., BMPs, protective notations, area operating agreements].

The means for protecting integrity of nesting areas will depend on the land type (public versus private).

On public lands:

- BMPs for land use activities will be developed, and implemented in collaboration with directly affected stakeholders.

- BMPs will incorporate the existing guidelines on setback distances and timing constraints for burrowing owls (see Section 6.2, Retaining or Increasing Habitat); guidelines will be reviewed periodically, in consultation with the Recovery Team, and affected stakeholders.

- Research will be undertaken to better define the setback distances and threshold limits for land use activities, including auditory disturbance and cumulative effects (Year 3, co-lead by Alberta Sustainable Resource Development and Environment Canada).

- Nest sites and surrounding areas within occupied or recently occupied home ranges will be protected (e.g., Protective Notations). Compliance monitoring will be provided (Alberta Fish and Wildlife Division, Public Lands and Forests Division), in collaboration with stakeholders.

- Actions will be taken, particularly through development of BMPs, Protective Notations, and Area Operating Agreements, to ensure that both the quality and quantity of lands that currently support or have supported burrowing owls within the previous 2 years are maintained, as part of the functional grassland landscape. Preventative measures will be applied in these parcels, to ensure that lands are not broken or cultivated, and to mitigate effects of disturbance.

- A discussion paper will be initiated by Alberta Sustainable Resource Development in Year 1 that recommends pre-development inventories to avoid and mitigate impacts on species at risk.

On private lands:

- Landowners and industry will be advised of existing BMPs and encouraged to adopt them (lead roles by Alberta Fish and Wildlife Division, OGC). Landowners and industry will be advised of relevant legislation involving species at risk. Landowners and industry will also be advised of the value of pre-development surveys. Compliance will be strongly encouraged. 
1. Improve inventory data

- Examine habitat quality in nesting areas occupied within recent years, but presently unoccupied, to determine whether changes to habitat in these areas may explain why these sites are currently unoccupied (include measures of ambient sound).

- Include data from pre-development surveys in an inventory database.

2. Test and Improve BMPs

- Determine why burrowing owls are no longer occupying vacant nesting sites, using resource selection analyses, and considering cumulative effects.

- Include practices that will increase food supplies in BMPs (raptors, including burrowing owls, respond positively to abundance of small mammals; therefore, improving habitat quality for microtine prey should benefit burrowing owls).

- Include practices that encourage minimal disturbance of native prairie.

3. Habitat Restoration

- Conduct trials on habitat adjacent to occupied nesting areas. These are important, strategic habitats for population recovery.

- Restore grasslands using natural recovery, where applicable, or alternatively, using native seed mixes, once requisite research has been completed.

4. Restoration of Potential Habitats

- Integrate BMPs for all species at risk in burrowing owl range.

- Protect native grasslands from degradation, cultivation, and unreasonable physical disturbance.

- Improve scientific understanding of critical elements of habitats for burrowing owls, through collaborative efforts with landholders and other stakeholders.

5. Population Intervention

- Reduce road mortalities (e.g., signage, educational programs).

- Reduce predation (e.g., remove perches near nests, increase small mammal abundance to reduce predation on burrowing owls).

- Increase burrowing owl foods by maintaining taller grass in foraging areas, especially swales, and increased diversity of habitats. 


\subsection{TIMETABLE FOR IMPLEMENTATION AND SCHEDULE OF COSTS}

Implementation summary for priority recovery actions in the action plan, including lead roles, recommended timing, and estimated total direct costs (thousands of dollars, totalled over the five years).

\begin{tabular}{lccc}
\hline Action Item & Lead Role $^{1}$ & Year(s) & Total cost (thousands) \\
\hline Direct inventory & ASRD $^{2}$ & $1-5$ & 150 \\
Develop, test HSI models & ASRD & $1-2$ & 30 \\
Identify essential habitat & ASRD, EC & 2 & 30 \\
Develop, test, refine BMPs & ASRD & $2-3$ & 60 \\
Research: thresholds, cumulative effects & ASRD, EC & 3,4 & 150 \\
Assess recently occupied nest sites & ASRD & 3 & 30 \\
Restore important habitats & ASRD & $2-5$ & 100 \\
Restore potential habitats & ASRD & $3-5$ & 100 \\
Signage, population intervention & ASRD & $1-5$ & 40 \\
\hline \hline Total & & & 690 \\
\hline
\end{tabular}

${ }^{1}$ Lead agencies will be responsible for coordination and facilitation of recovery actions

${ }^{2}$ Alberta Sustainable Resource Development

${ }^{3}$ Environment Canada

\subsection{PLAN REVIEW, AMENDMENT, AND IMPLEMENTATION}

This recovery plan will be implemented for a five-year period, and reviewed annually during that period. The Alberta Burrowing Owl Recovery Team will facilitate and monitor implementation of the action plan and determine effectiveness of recovery actions. A report summarizing the results of those reviews will be submitted annually to the Director of Wildlife Management. Recovery plans are considered "living" documents and can be amended during these reviews. At the end of five years, the recovery team will meet to determine whether any other amendments are required, prior to the plan being renewed for another five years. The team may determine that the existing recovery plan is suitable, in need of minor edits, or in need of a major revision.

Alberta Sustainable Resource Development (ASRD) will oversee plan implementation with the Recovery Team, and will be responsible for plan management and administration. Approaches and actions that support the Recovery Strategies (Section 5.4) will be facilitated opportunistically as follows:

- In general, ASRD and Operation Grassland Community (OGC) are expected to take the lead role with actions in the rangeland management and stewardship area (6.1), with Environment Canada (EC) sharing involvement in research on best management practices (6.1.3).

- ASRD will generally take the lead role with actions involving retaining or increasing habitat (6.2), although substantive involvement of several partners [Alberta Conservation Association, EC, Canadian Forces Base Suffield (CFBS), Eastern Irrigation District (EID), private industry] will be integral to achieving several action items successfully $(6.2 .1 .1$, 6.2.1.3, 6.2.1.5, 6.2.1.6, 6.2.3, 6.2.4.3).

- ASRD and OGC will share lead roles in the public education and awareness area (6.3). 
- ASRD has the lead role for actions involving optimizing survival in Alberta (6.4), although OGC and EC may contribute importantly in public awareness $(6.4 .2,6.4 .3)$ and research initiatives (6.4.2.3), respectively.

- With respect to determining causes of decline (6.5), ASRD and EC are co-leaders, considering that findings in jurisdictions outside Alberta (e.g., Saskatchewan) could have direct relevance in the province (e.g., 6.5.1, 6.5.2, 6.5.3, 6.5.4.2).

- In general, ASRD will take the lead role on actions seeking to optimize burrowing owl productivity (6.6), although involvement of EID and CFBS may be essential to achieving full success (e.g., 6.6.1, 6.6.2.3).

- Lead responsibilities for population monitoring vary with scale (e.g., OGC for 6.7.1, ASRD for 6.7.2).

Most actions will be ongoing through the life span of this plan. It is anticipated that a variety of agencies and organizations (public and private) will participate in the funding and implementation of activities identified in the action plan (see Section 7, Action Plan, and Section 8 , Timetable for Implementation).

In summary, successful attainment of many action items in this recovery plan will hinge on the effective involvement of many individuals, agencies, and organizations, including private industry. The effective involvement of all concerned Albertans may be necessary to ensure that burrowing owls are not lost to extinction as a result of human activities.

\subsection{SOCIO-ECONOMIC CONSIDERATIONS}

Maintenance and recovery actions for burrowing owls will be guided by the principles identified in Section 1.3 of this Plan. The stewardship efforts of landholders lend themselves to strengthening relationships with other stakeholders, with attendant benefits to grassland ecosystems, and resident wildlife species, including burrowing owls. Direct and indirect costs to landholders and industry are factors that must be carefully considered.

A number of sectors may be affected by actions recommended within the Recovery Plan, including agriculture (farming and ranching), other industry (oil and gas, mining, municipal development), recreation, and natural capital. A brief treatment of each of these four sectors follows.

\section{Agriculture}

The agricultural community may benefit through stabilization of the grassland region, and more specifically, the grazing resource. Ranching operations may benefit through public recognition of the need for a mosaic of range conditions that tends to be a part of every well-managed livestock holding. Public support for traditional ranching (as being environmentally conducive in terms of field practices and associated lifestyle) is anticipated to increase.

There may be some adjustments to traditional grazing practices where deferred rotations are identified through development of BMPs. It is conceivable, for example, that fencing or water development may be recommended to manage livestock movement in or near essential burrowing owl habitat at certain times of the year. 


\section{Other Industry}

There can be increased recognition and support for those developers/operators that demonstrate responsible conservation practices by accepting constraints that benefit the needs of burrowing owls and other species. There may be some cost adjustments incurred by industry when planning or implementing developments to accommodate the needs of species at risk.

\section{Recreation}

Recreational opportunities may be enhanced, generally, due to the stewardship efforts of landholders that offer an unparalleled grassland recreation experience. Increased recreation and eco-tourism can bring sustainable revenue to the local community. This helps stabilize both regional services and economy. Increased recreation can enhance relationships between visitors and local residents. This can lead to increased understanding and respect for the needs and interests of each by the other.

Landowners and occupants may feel obligated to monitor the actions of visitors more closely to ensure that habitats, wildlife or livestock are neither damaged nor disturbed. Land stewards may feel additional responsibilities as gatekeepers of the natural landscape. Nesting areas for burrowing owls must, of course, be safe-guarded from disturbance by recreational users (and others).

\section{Natural Capital}

The landscape will benefit through maintaining or enhancing biodiversity and the production of biomass. This will help reduce the potential for desertification of the grasslands region through cultivation, overgrazing, or industrial development. Society may need to actively reduce the fragmentation of the landscape by minimizing the intrusive nature of commercial/industrial development, and the infrastructure of roads to support it.

Implementation of the Recovery Plan will result in sustained and enhanced habitat opportunities for both flora and fauna. This will augment the public comfort level, knowing that grassland stewardship values are the driving force behind landscape conservation.

Recovery planning and implementation has the positive potential to increase awareness of the needs of species at risk, and associated habitat considerations. This can be shared at the level of a broad population spectrum (e.g., provincially), as well as locally. 


\subsection{LITERATURE CITED}

Alberta Sustainable Resource Development. in press. Status of the burrowing owl (Athene cunicularia) in Alberta: update 2005. Alberta Sustainable Resource Development, Fish and Wildlife Division, and Alberta Conservation Association, Edmonton, AB.

Clayton, K. M. 1997. Post-fledging ecology of burrowing owls in Alberta and Saskatchewan: dispersal, survival, habitat use, and diet. M.Sc. Thesis, Univ. of Saskatchewan, Saskatoon, SK. 66 pp.

Clayton, K. M., and J. K. Schmutz. 1999. Is the decline of Burrowing Owls (Speotyto cunicularia) in prairie Canada linked to changes in Great Plains ecosystems? Bird Conservation International 9:163-185.

Gleason, R. S. 1978. Aspects of the breeding biology of burrowing owls in southeastern Idaho. M.Sc. Thesis, Univ. of Idaho, Moscow. 47 pp.

Haug, E., and L. W. Oliphant. 1990. Movements, activity patterns, and habitat use of burrowing owls in Saskatchewan. Journal of Wildlife Management 54:27-35.

Hjertaas, D. G., S. Brechtel, K. DeSmet, O. Dyer, E. A. Haug, G. Holroyd, P. C. James, and J. K. Schmutz. 1995. National recovery plan for the burrowing owl. A report prepared for the Committee for the Recovery of Nationally Endangered Wildlife. Canadian Wildlife Federation, Ottawa. ON. 33 pp.

Hoyt, J. S., T. I. Wellicome, K. D. DeSmet, J. K. Schmutz, P. C. James, K. M. Clayton, R. Poulin, L. D. Todd, G. Holroyd, and D. Stepnisky. 2001. Survival estimates for three burrowing owl populations in prairie Canada. Canadian Wildlife Service Internal Report, Edmonton, AB.

Hull, K., A. Bogen, J. Boyle, and C. Wickenheiser. 2004. Beneficial management practices for the Milk River Basin, Alberta: A component of the Multi-species Conservation Strategy for Species at Risk in the Milk River Basin (Multisar). Unpublished rept. prep. for Alberta Sustainable Resource Development, Fish and Wildlife Division, and Alberta Conservation Association. Rangeland Conservation Service Ltd., Airdrie, AB. 369pp.

James, P. C., and G. A. Fox. 1987. Effects of some insecticides on productivity of burrowing owls. Blue Jay 45:65-71.

James, P. C., G. A. Fox, and T. J. Ethier. 1990. Is the operational use of strychnine to control ground squirrels detrimental to burrowing owls? Journal of Raptor Research 24:120-123.

James, P. C., T. J. Ethier, G. A. Fox, and M. Todd. 1991. New aspects of burrowing owl biology. Pp 226-227 In Proceedings of the second endangered species and prairie conservation workshop (Holroyd, G.L., G. Burns, and H.C. Smith, eds.) Natural History Occasional Paper No 15. Provincial Museum of Alberta, Edmonton, AB. 
Plumpton, D. L. 1992. Aspects of nest site selection and habitat use by burrowing owls at the Rocky Mountain Arsenal, Colorado. M.S. Thesis, Texas Tech Univ., Lubbock, Texas. $65 \mathrm{pp}$.

Russell, R. F. 2002. 2002 Burrowing owl trend block survey and monitoring, Brooks area. Alberta Sustainable Resource Development, Fish and Wildlife Division, Alberta Species at Risk Report No. 58, Edmonton, AB. 10pp.

Schmutz, J. K., R. W. Fyfe, D. A. Moore, and A. R. Smith. 1984. Artificial nests for Ferruginous and Swainson's Hawks. Journal of Wildlife Management 48:1009-1013.

Scobie, D., and C. Faminow. 2000. Development of standardized guidelines for petroleum industry activities that affect COSEWIC Prairie and Northern Region vertebrate species at risk. Environment Canada, Edmonton, AB. 5 pp. + appendices.

Shyry, D., and L. D. Todd. 2000. Juvenile burrowing owl demographics and movements: a summary of productivity, recruitment, post-fledging mortality, and dispersal in the Saskatchewan and Alberta populations. Unpublished report for The Endangered Species Recovery Fund. $15 \mathrm{pp}$.

Shyry, D. T., T. I. Wellicome, J. K. Schmutz, G. L. Erickson, D. L. Scobie, R. F. Russell, and R. G. Martin. 2001. Burrowing owl population-trend surveys in southern Alberta: 19912000. Journal of Raptor Research 35:310-315.

Sleno, J. 2000. Possible cat predation on burrowing owls. Blue Jay 58(4):191-192.

Todd, D. 2001a. Survival and dispersal of juvenile burrowing owls (Athene cunicularia) during the post-fledging, pre-migratory period. M.Sc. Thesis, Univ. of Regina, SK. $76 \mathrm{pp}$.

Todd, D. 2001b. Dispersal patterns and post-fledging mortality of juvenile burrowing owls in Saskatchewan. Journal of Raptor Research 35:282-287.

Warnock, R. G., and M. A. Skeel. 2001. Habitat features important to burrowing owl (Speotyto cunicularia) breeding success in Saskatchewan. Report to Environment Canada, Edmonton, AB and Saskatchewan Environment and Resource Management, Regina, SK. Nature Saskatchewan, Regina, SK. 17pp.

Wellicome, T. I. 1997a. Status of the Burrowing Owl (Speotyto cunicularia hypugaea) in Alberta. Alberta Environmental Protection, Wildlife Management Division, Wildlife Status Report No. 11, Edmonton, AB. 21 pp.

Wellicome, T. I. 1997b. Reproductive performance of burrowing owls (Speotyto cunicuolaria): effects of supplemental food. Journal of Raptor Research Report 9:68-73. 
Wellicome, T. I., and E. A. Haug. 1995. Second update of status report on the burrowing owl Speotyto cunicularia in Canada. Report prepared for the Committee on the Status of Endangered Wildlife in Canada, Canadian Wildlife Service, Ottawa, ON. 32 pp.

Wellicome, T. I., and G. L. Holroyd. 2001. The second international burrowing owl symposium: background and context. Journal of Raptor Research 35: 269-273.

Zarn, M. 1974. Burrowing owl, report no. 11. Habitat management service for unique or endangered species, U.S. Department of the Interior, Bureau of Land Management, Denver, Colorado. $25 \mathrm{pp}$. 


\section{List of Titles in the Alberta Species at Risk Recovery Plan Series}

(as of December 2005)

No. 1 Maintenance and Recovery Plan for Western Blue Flag (Iris missouriensis) in Canada. (2002)

No. 2 Alberta Piping Plover Recovery Plan 2002-2004. (2002)

No. 3 Alberta Peregrine Falcon Recovery Plan 2004-2010. (2005)

No. 4 Alberta Woodland Caribou Recovery Plan 2004/05-2013/14. (2005)

No. 5 Recovery Plan for Ord's Kangaroo Rat in Alberta. (2005) 






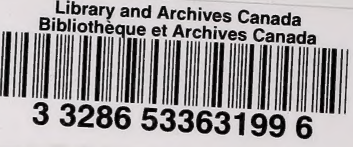

